\title{
A trial of ascorbic acid in the treatment of the common cold
}

\author{
D. A. J. TYRRELL AND J. WALLACE CRAIG \\ From the MRC Common Cold Research Unit and Clinical Research Centre, Harrow
}

T. W. MEADE AND TRISHA WHITE

From the MRC/DHSS Epidemiology and Medical Care Unit, Northwick Park Hospital, Harrow

SUMMARY A randomised controlled trial was carried out to study the effect of $10 \mathrm{~g}$ of ascorbic acid taken during the first $2 \frac{1}{2}$ days on the symptoms of the common cold. Altogether 1524 volunteers were recruited from a number of working groups in different parts of the country; 482 developed colds. There was no evidence that upper respiratory or general constitutional symptoms were alleviated by ascorbic acid. Among the men who had any colds at all, significantly fewer on active than on placebo treatment had two or more colds; however, this effect was not seen in women. Ascorbic acid is of no value in the treatment of the common cold; its preventive effect, if any, is not such as to justify advising its general use as a prophylactic measure.

Large doses of ascorbic acid (vitamin C) have been used for many years for the prevention and treatment of common colds, and this practice has been strongly endorsed by Pauling (1970). Some controlled trials have been undertaken and the evidence obtained from them has recently been reviewed (Tyrrell, 1974; Chalmers, 1975; British Medical Journal, 1976). Ascorbic acid metabolism is clearly disturbed during colds as the blood leucocyte concentration is significantly reduced (Hume and Weyers, 1973), but there is no good evidence that taking large doses of 1 to $3 \mathrm{~g}$ daily as prophylaxis reduces the overall incidence of colds. However, from studies of adults in Toronto (Anderson et al., 1972, 1974) it did appear that taking up to $8 \mathrm{~g}$ daily reduced the constitutional upset, and thus the number of days in bed or off work, once a cold had started. Coulehan et al. (1974) concluded that $1 \mathrm{~g}$ a day reduced the incidence of respiratory symptoms in children without reducing the number of colds. Wilson and Loh (1973) also claim that ascorbic acid has a beneficial effect on colds. Considered as a whole, these results suggest the possibility that large doses of ascorbic acid taken at the start of a cold may correct some metabolic disturbance induced by the disease and thus reduce its clinical manifestations. Such an effect may be seen in some populations and not in others, and could be of clinical and economic importance if it prevented the patient going to bed or having time off work. We therefore carried out a clinical trial on representative groups of volunteers in the climatic, cultural, and nutritional environment of the United Kingdom.

\section{Methods}

A total of 1524 people, 753 men and 771 women, entered into the trial. They were recruited from two retail stores, an engineering plant, the headquarters and one of the production sites of a large industrial group, a local government office, and the staff of a hospital; these were situated in Salisbury, in or near London, and on Merseyside.

Each volunteer was given a tube of 10 effervescent tablets. All 10 tablets in the tubes with 'active treatment', contained $1 \mathrm{~g}$ of ascorbic acid; all those in the tubes with 'placebo treatment', contained inert substances of identical appearance and taste. Allocation to active or placebo treatment was made at random. A small subsidiary trial confirmed that volunteers could not detect the difference between the two preparations by taste. However, in order to minimise the possibility that volunteers in the different participating centres might, by comparing notes, be able (or consider they were able) to identify which individuals had been given the active tablets and which the placebo, 10 code letters were used for the tubes in which the tablets were packed ( 5 for active and 5 for placebo tablets); neither the volunteer nor the trial organiser was aware which was the active and which was the placebo code until after the study. Each volunteer was also given a 
simple card on which to record the presence or absence of specified symptoms in the event of a cold, and a sheet of instructions on the procedure for taking the tablets and completing the form. Four tablets were taken daily for a total of $2 \frac{1}{2}$ days, and each symptom on the card was marked as being present or absent on each day during the time the cold lasted. Volunteers were told to start taking the tablets as soon as they experienced the first symptoms of what they anticipated would be a cold. The cards of those who developed colds were collected and a new card and a fresh supply of tablets (of the same code letter) were issued in case of another cold. The trial ran from December 1975 to April 1976. Records for 23 volunteers who developed colds (10 on active treatment; 13 on placebo) were excluded because treatment was discontinued when another illness (for example, influenza) was diagnosed or because cards were spoiled, etc.

\section{Results}

Table 1 shows the number of men and women in the two groups; it also shows the numbers who developed one cold or more, and it is clear that these occurred with equal frequency between those on active and placebo treatment. About $30 \%$ of all the volunteers had at least one cold, the figure being a little higher in men.

Table 1 Numbers and percentages of volunteers given ascorbic acid or placebo tablets, and of those developing colds (one or more)

\begin{tabular}{|c|c|c|c|c|c|c|}
\hline & \multicolumn{2}{|c|}{ No colds } & \multicolumn{2}{|c|}{ Colds } & \multicolumn{2}{|c|}{ Total } \\
\hline & No. & $\%$ & No. & $\%$ & No. & $\%$ \\
\hline $\begin{array}{l}\text { Men } \\
\text { Active } \\
\text { Placebo }\end{array}$ & $\begin{array}{l}227 \\
251\end{array}$ & $\begin{array}{l}65 \\
67\end{array}$ & $\begin{array}{l}124 \\
141\end{array}$ & $\begin{array}{l}35 \\
36\end{array}$ & $\begin{array}{l}351 \\
392\end{array}$ & $\begin{array}{l}100 \\
100\end{array}$ \\
\hline $\begin{array}{c}\text { Women } \\
\text { Active } \\
\text { Placebo }\end{array}$ & $\begin{array}{l}272 \\
269\end{array}$ & $\begin{array}{l}73 \\
70\end{array}$ & $\begin{array}{l}101 \\
116\end{array}$ & $\begin{array}{l}27 \\
30\end{array}$ & $\begin{array}{l}373 \\
385\end{array}$ & $\begin{array}{l}100 \\
100\end{array}$ \\
\hline $\begin{array}{l}\text { Both } \\
\text { Active } \\
\text { Placebo }\end{array}$ & $\begin{array}{l}499 \\
520\end{array}$ & $\begin{array}{l}69 \\
67\end{array}$ & $\begin{array}{l}225 \\
257\end{array}$ & $\begin{array}{l}31 \\
33\end{array}$ & $\begin{array}{l}724 \\
777\end{array}$ & $\begin{array}{l}100 \\
100\end{array}$ \\
\hline Total & 1019 & 68 & 482 & 32 & 1501 & 100 \\
\hline
\end{tabular}

Records for 23 volunteers excluded (see text) in this and other tables

There was no evidence in those who developed colds that either the upper respiratory or the general constitutional symptom was alleviated by active treatment. Symptoms and time in bed and off work are shown in Table 2; the recorded duration of each symptom was rather more for women than men, and the total mean duration of colds (that is, days on which a symptom of any sort was recorded regardless of the duration of any particular symptom) was also longer for women than men.
Table 2 Duration in days of symptoms per cold ${ }^{*}$, and total duration, in those developing colds (one or more). Means and standard deviations

\begin{tabular}{|c|c|c|c|c|c|}
\hline \multirow[t]{2}{*}{ Duration and symptom } & \multirow{2}{*}{$\begin{array}{l}\text { Treatment } \\
\text { group }\end{array}$} & \multicolumn{2}{|l|}{ Men } & \multicolumn{2}{|c|}{ Women } \\
\hline & & Mean & $S D$ & Mean & $S D$ \\
\hline Runny nose & $\begin{array}{l}\text { Active } \\
\text { Placebo }\end{array}$ & $\begin{array}{l}3.23 \\
3.46\end{array}$ & $\begin{array}{l}2 \cdot 76 \\
3 \cdot 21\end{array}$ & $\begin{array}{l}4 \cdot 16 \\
3 \cdot 20\end{array}$ & $\begin{array}{l}4 \cdot 310 \\
3 \cdot 35 \bar{C}\end{array}$ \\
\hline Muscular aches & $\begin{array}{l}\text { Active } \\
\text { Placebo }\end{array}$ & $\begin{array}{l}0 \cdot 71 \\
0 \cdot 73\end{array}$ & $\begin{array}{l}1 \cdot 22 \\
1 \cdot 48\end{array}$ & $\begin{array}{l}1 \cdot 16 \\
0.97\end{array}$ & $\begin{array}{l}2 \cdot 43 \frac{\overline{ }}{1 \cdot 58} \\
\frac{C}{J}\end{array}$ \\
\hline Days in bed & $\begin{array}{l}\text { Active } \\
\text { Placebo }\end{array}$ & $\begin{array}{l}0 \cdot 21 \\
0 \cdot 20\end{array}$ & $\begin{array}{l}0.65 \\
0.63\end{array}$ & $\begin{array}{l}0.47 \\
0.53\end{array}$ & $\begin{array}{l}1 \cdot 00 \bar{D} \\
1 \cdot 680\end{array}$ \\
\hline Days off work & $\begin{array}{l}\text { Active } \\
\text { Placebo }\end{array}$ & $\begin{array}{l}0.46 \\
0.46\end{array}$ & $\begin{array}{l}1 \cdot 22 \\
1 \cdot 19\end{array}$ & $\begin{array}{l}1.03 \\
1.07\end{array}$ & $\begin{array}{l}2 \cdot 19 \text { ) } \\
2 \cdot 72 \text { ( }\end{array}$ \\
\hline Total duration of cold & $\begin{array}{l}\text { Active } \\
\text { Placebo }\end{array}$ & $\begin{array}{l}7 \cdot 41 \\
7 \cdot 57\end{array}$ & $\begin{array}{l}3 \cdot 59 \\
3 \cdot 79\end{array}$ & $\begin{array}{l}8 \cdot 96 \\
8 \cdot 24\end{array}$ & $\begin{array}{l}5 \cdot 30 \\
4 \cdot 78\end{array}$ \\
\hline
\end{tabular}

* Results based on total number of colds, not on number of volunteers $\vec{\omega}$ who developed colds.

Other comparisons were made (for example, $\stackrel{\text {, }}{\vec{\omega}}$ analysing only the symptoms occurring on the three days during which the tablets were taken, $\omega$ omitting 'colds' reported during an outbreak of influenza); but none of these analyses showed anyo difference between the two treatment groups so far. as cold symptoms or duration was concerned. $O$

Table 3 shows the only finding of possible interest. Among the men who had any colds at a 9 significantly fewer on active treatment than ono placebo had two or more; this effect was not seenn in the women.

Table 3 Numbers of volunteers having one or two (or more) colds, by treatment group

\begin{tabular}{llll} 
& No. of colds & & \\
\cline { 2 - 4 } & One & Two (or more) & \\
\hline Men & & $\mathbf{P}<0.05$ \\
$\begin{array}{c}\text { Active } \\
\text { Placebo }\end{array}$ & 101 & 23 & \\
Women & 98 & 43 & NS \\
Active & 75 & 26 & \\
Placebo & 87 & 29 & \\
\hline
\end{tabular}

NS Not significant.

\section{Discussion}

As a prelude to this study a small trial at Salisbury was carried out on 135 volunteers who between them had 66 colds. Eight of those on ascorbic acid wereo off work for an average of 1.6 days, and 11 on the placebo were off for $2 \cdot 2$ days; there was a similaro finding for number of days in bed, and these two differences just reached a conventional level of statistical significance. There were no differences fon the upper respiratory symptoms such as sneezingu and sore throat (Craig et al., unpublished). However $\sigma$ the numbers studied were small, which was the main reason for proceeding to the larger trial now reported. The results lend no support to the value? 
of ascorbic acid for the amelioration of the symptoms of the common cold. Carson et al. (1975) using $1 \mathrm{~g}$ of ascorbic acid daily have also reported that ascorbic acid appears to be without effect, and Karlowski et al. (1975) reached a similar conclusion (although in this case the results had to be re-evaluated after it was realised that the volunteers were correctiy guessing which preparation they were taking). These reports confirm those made earlier by Walker et al. (1967), Schwartz et al. (1973), and by the General Practitioner Research Group (1968). Elwood et al. (1977) reported only small or inconsistent effects attributable to ascorbic acid and Coulehan et al. (1976) did not find the effect they had reported before.

Our trial was designed to assess the value of ascorbic acid in ameliorating symptoms once a cold had started, and not its effect in preventing onset. Our finding that ascorbic acid appears to effect a small reduction in the numbers of men having second or subsequent colds was therefore unexpected. We cannot say whether there would have been a similar effect on first colds had the trial been designed to test the prophylactic as well as ameliorative value of ascorbic acid. Elwood et al. (1977) also found a small reduction in repeated colds in pregnant women given regular ascorbic acid. We can offer no explanation for this apparently preventive effect if it is genuine, but we do not believe it has much practical implication. Having had one cold, the chances of a second or subsequent cold appear to be about $20 \%$ if ascorbic acid is taken at the onset of the first, compared with about $30 \%$ if it is not. It is doubtful whether this reduction (or a similar reduction in the chance of having a first cold, if the effect were also seen in these circumstances) justifies recommending the use of ascorbic acid (which is not cheap) on community health grounds, although individuals may, of course, decide for themselves that taking it is worthwhile. In general, however, our view is that there is no case, on preventive or therapeutic grounds, for recommending ascorbic acid against the common cold.

We wish to thank all those who helped to organise and who took part in the trial at the participating centres - Kodak Ltd, Wellworthy Ltd, Marks and Spencer Ltd, Debenhams Ltd, the London Borough of Harrow, and Northwick Park Hospital and Clinical Research Centre. We also acknowledge valuable help from Mrs A. Rohan, Mrs K. Clark, Mrs B. Mennie, Mr P. J. Brennan, Mr W. R. S. North, and Mr J. Hall at Northwick Park, and Mrs W. Thompson at Salisbury.
Reprints from D. A. J. Tyrrell, MRC Clinical Research Centre, Northwick Park Hospital, Division of Communicable Diseases, Watford Road, Harrow, Middlesex HA1 3UJ.

\section{References}

Anderson, T. W., Reid, D. B., and Beaton, G. H. (1972). Vitamin $\mathrm{C}$ and the common cold: $\mathbf{A}$ double blind trial. Canadian Medical Association Journal, 107, 503-508.

Anderson, T. W., Suranyi, G., and Beaton, G. H. (1974). The effect on winter illness of large doses of vitamin C. Canadian Medical Association Journal, 111, 31-36.

British Medical Journal (1976). Editorial: Vitamin C and the common cold. British Medical Journal, 1, 606-607.

Carson, M., Cox, H., Corbett, M., and Pollitt, N. (1975). Vitamin $\mathrm{C}$ and the common cold. Journal of the Society of Occupational Medicine, 25, 99-102.

Chalmers, T. C. (1975). Effects of ascorbic acid on the common cold: An evaluation of the evidence. American Journal of Medicine, 58, 532-536.

Coulehan, J. L., Eberhard, S., Kapner, L., Taylor, F., Rogers, K., and Garry, P. (1976). Vitamin C and acute illness in Navajo schoolchildren. New England Journal of Medicine, 295, 973-977.

Coulehan, J. L., Reisinger, K. S., Rogers, K. D., and Bradley, D. W. (1974). Vitamin C prophylaxis in a boarding school. New England Journal of Medicine, 290, 6-10.

Elwood, P. C., Hughes, S. J., and St. Leger, A. S. (1977). A randomized controlled trial of the therapeutic effect of vitamin $\mathrm{C}$ in the common cold. Practitioner, 218, 133-137.

General Practitioner Research Group (1968). Ineffectiveness of vitamin $\mathrm{C}$ in treating coryza. Practitioner, 200, 442-445.

Hume, R., and Weyers, E. (1973). Changes in leucocyte ascorbic acid during the common cold. Scottish Medical Journal, 18, 3-7.

Karlowski, T. R., Chalmers, T. C., Frenkel, L. D., Kapikian, A. Z., Lewis, T. L., and Lynch, J. M. (1975). Ascorbic acid for the common cold. A prophylactic and therapeutic trial. Journal of the American Medical Association, 231, 1038-1042.

Pauling, L. (1970). Vitamin C and the Common Cold. Freeman: San Francisco.

Schwartz, A. R., Togo, Y., Hornick, R. B., Tominaga, S., and Gleckman, R. A. (1973). Evaluation of the efficacy of ascorbic acid in prophylaxis of induced rhinovirus 44 infection in man. Journal of Infectious Diseases, 128, 500-505.

Tyrrell, D. A. J. (1974). Vitamin C and the common cold. Prescribers Journal, 14, 21-24.

Walker, G. H., Bynoe, M. L., and Tyrrell, D. A. J. (1967). Trial of ascorbic acid in prevention of colds. British Medical Journal, 1, 603-606.

Wilson, C. W. M., and Loh, H. S. (1973). Common cold and vitamin C. Lancet, 1, 638-641. 